\title{
PRODUCTION, ISOLATION AND PROPERTIES OF PYRACRIMYCIN A, A NEW ANTIBIOTIC FROM STREPTOMYCES ERIDANI N. SP.
}

\author{
G. Coronelli, G. Tamoni, G. Beretta and G. C. Lancini \\ Research Laboratories, Gruppo Lepetit S.p.A., Milano, Italy \\ (Received for publication February 6, 1971)
}

\begin{abstract}
Two new compounds, pyracrimycins $\mathrm{A}$ and $\mathrm{B}$, have been isolated from a Streptomyces species named Streptomyces eridani Coronelli et al. n. sp. The morphological and physiological characteristics of this strain are described in the present paper together with the production and properties of the two metabolites. Pyracrimycin B is biologically inactive whereas pyracrimycin $A$ is active in vitro against both Gram-positive and Gram-negative bacteria.
\end{abstract}

During the course of our screening program for new antimicrobial agents two chemically-related substances, one of which active in vitro against Gram-positive and Gram-negative bacteria, were isolated from a Streptomyces strain. The producing organism, isolated from a soil sample collected in Pavia (Italy) was named Streptomyces eridani Coronelli et al. n. sp. (ATCG 21619) and the products isolated were named pyracrimycins $\mathrm{A}$ and $\mathrm{B}$.

The present paper deals with the description of the producing strain, the isolation of the two metabolites and the biological properties of pyracrimycin A.

\section{Description of the Producing Strain}

For the investigation of the growth characteristics S. eridani was grown on a variety of standard media according to GotTlieb and ShiRLing ${ }^{1)}$; in addition some media recommended by WAKSMAN ${ }^{2)}$ were used. The optimum temperature range for development of the colonies was from $28^{\circ}$ to $37^{\circ} \mathrm{C}$, no growth was observed at $50^{\circ} \mathrm{C}$ and very little at $20^{\circ} \mathrm{C}$. Cultural and physiological characteristics of the Streptomyces are shown in Table 1.

Aerial mycelium is produced by S. eridani only on oat-meal agar and potato agar. On the latter the aerial mycelium produced is scanty and no sporulation was observed; in oat-meal agar the aerial mycelium is white, velvety with long, flexous and branched hyphae having a diameter of about $1.3 \mu$. Aerial mycelium produces sporophores in fairly closed spirals different in their lengths. The spores are oval with smooth surface and have diameters of about 1 1.3 $\mu \times 1.3 \sim 1.5 \mu$. Based on the form of the sporophores and on the color of the aerial mycelium, S. eridani was assigned to the Section Spira, White Series according to the classification of PridHAM, Hesseltine and Benedict ${ }^{5}$. The test for utilization of carbon sources performed according to Pridham and GotTlieb ${ }^{6}$ are shown in Table 2. All the compounds tested are utilized carbon sources tested except cellulose. 
Table 1. Cultural and physiological characteristics of Streptomyces eridani (ATCC 21619)

\begin{tabular}{|c|c|c|c|c|}
\hline Culture medium & Vegetative mycelium & Aerial mycelium & Soluble pigment & $\begin{array}{l}\text { Physiological } \\
\text { characteristics }\end{array}$ \\
\hline Oat-meal agar & $\begin{array}{l}\text { Good growth, smooth } \\
\text { surface cream }\end{array}$ & Whitish in traces & $\begin{array}{l}\text { Cream to light } \\
\text { amber } 12 / \mathrm{G} / 7^{*}\end{array}$ & \\
\hline $\begin{array}{l}\text { Medium } 2 \\
\text { (GotTlieb and } \\
\text { ShIRLING) }\end{array}$ & $\begin{array}{l}\text { Good growth, slightly } \\
\text { wrinkled amber } 13 / \mathrm{E} / 7 *\end{array}$ & Absent & $\begin{array}{l}\text { Amber brown } \\
13 / \mathrm{F} / 9^{*}\end{array}$ & \\
\hline $\begin{array}{l}\text { Oat-meal agar } \\
\text { (Medium } 3 \\
\text { GotTLIEB and } \\
\text { SHIRLING) }\end{array}$ & $\begin{array}{l}\text { Moderate growth, } \\
\text { smooth surface hyaline }\end{array}$ & $\begin{array}{l}\text { White, velvety, } \\
\text { not much } \\
\text { abundant }\end{array}$ & Absent & \\
\hline $\begin{array}{l}\text { Glycerol asparagine } \\
\text { agar (Medium 5) }\end{array}$ & $\begin{array}{l}\text { Good growth, smooth } \\
\text { surface cream }\end{array}$ & Absent & Absent & \\
\hline $\begin{array}{l}\text { Hickey and } \\
\text { TresneR's agar }{ }^{3)}\end{array}$ & $\begin{array}{l}\text { Good growth, slightly } \\
\text { wrinkled brown } \\
\text { 16/A/10* }\end{array}$ & Absent & $\begin{array}{l}\text { Deep amber } \\
\text { brown } 15 / \mathrm{L} / 12^{*}\end{array}$ & \\
\hline BENNETT's agar & $\begin{array}{l}\text { Good growth, wrinkled } \\
\text { surface amber brown } \\
14 / 4 / 7^{*}\end{array}$ & Absent & $\begin{array}{l}\text { Amber brown } \\
14 / 1 / 9 *\end{array}$ & \\
\hline $\begin{array}{l}\text { CzaPek glucose } \\
\text { agar }\end{array}$ & $\begin{array}{l}\text { Moderate growth, } \\
\text { smooth surface straw } \\
9 / \mathrm{B} / 1^{*}\end{array}$ & Absent & Absent & \\
\hline $\begin{array}{l}\text { Glucose asparagine } \\
\text { agar }\end{array}$ & $\begin{array}{l}\text { Good growth, smooth } \\
\text { surface with wax } \\
\text { aspect, cream } 9 / \mathrm{D} / 2^{*}\end{array}$ & Absent & Traces, cream & \\
\hline Nutrient agar & $\begin{array}{l}\text { Growth scarce, thin } \\
\text { smooth surface amber } \\
\text { 13/H/8* }\end{array}$ & Absent & Amber $13 / \mathrm{H} / 8^{*}$ & . \\
\hline Potato agar & $\begin{array}{l}\text { Good growth, slightly } \\
\text { wrinkled surface, light } \\
\text { brown } 15 / \mathrm{E} / 7^{*}\end{array}$ & Whitish in traces & $\begin{array}{l}\text { Light brown } \\
15 / E / 7 *\end{array}$ & \\
\hline $\begin{array}{l}\text { Starch agar } \\
\text { (Medium 4) }\end{array}$ & $\begin{array}{l}\text { Moderate growth, } \\
\text { smooth surface, straw } \\
11 / C / 2^{*}\end{array}$ & Absent & Straw $11 / \mathrm{C} / 2^{*}$ & Good hydrolysis \\
\hline $\begin{array}{l}\text { Peptone-yeast } \\
\text { extract iron agar } \\
\text { (Medium 6) }\end{array}$ & $\begin{array}{l}\text { Moderate growth, } \\
\text { smooth surface brown } \\
\text { 16/A/8* }\end{array}$ & Absent & & $\begin{array}{l}\text { Production of } \\
\mathrm{H}_{2} \mathrm{~S}\end{array}$ \\
\hline $\begin{array}{l}\text { Tyrosine agar } \\
\text { (Medium } 7 \text { ) }\end{array}$ & $\begin{array}{l}\text { Good growth, wrinkled } \\
\text { surface black brown }\end{array}$ & Absent & $\begin{array}{l}\text { Black-brown at } \\
\text { the edges of the } \\
\text { growth, brown in } \\
\text { the medium } \\
15 / \mathrm{A} / 12^{*}\end{array}$ & $\begin{array}{l}\text { Tyrosinase reac- } \\
\text { tion: positive- } \\
\text { production of } \\
\text { melanoid pigment } \\
\text { (strong) }\end{array}$ \\
\hline $\begin{array}{l}\text { Calcium malate } \\
\text { agar }\end{array}$ & $\begin{array}{l}\text { Good growth, smooth } \\
\text { surface straw } 10 / \mathrm{B} / 1^{*}\end{array}$ & Absent & Absent & $\begin{array}{l}\text { Strong digestion } \\
\text { of } \mathrm{Ca} \text {-malate }\end{array}$ \\
\hline Gelatin & & & Absent & Liquefaction \\
\hline Nitrate broth & & & Dark brown & $\begin{array}{l}\text { Nitrate reduction } \\
\text { positive }\end{array}$ \\
\hline Litmus milk & Brown ring & & Absent & $\begin{array}{l}\text { No peptonization } \\
\text { no coagulation }\end{array}$ \\
\hline Skim milk agar & $\begin{array}{l}\text { Good growth, smooth } \\
\text { surface } 8 / \mathrm{A} / 12^{*}\end{array}$ & Absent & $\begin{array}{l}\text { Brown not much } \\
\text { soluble on the } \\
\text { medium } 8 / \mathrm{A} / 12^{*}\end{array}$ & $\begin{array}{l}\text { Hydrolysis of } \\
\text { casein: negative }\end{array}$ \\
\hline
\end{tabular}

* Color determinations were performed according to MAERz and PAUL4).

A comparison of $S$. eridani with some related strains is reported in Table 3. Among the known species of Streptomyces belonging to Section Spira, White Series, only Streptomyces albidus CBS 100.34, and Streptomyces armillatus NANCY-CourtiLLET and Pinnet-Sindico, 1954, show some similarity to Streptomyces eridani. However they differ from our strain mainly for the color of vegetative mycelium on several 
Table 2. Utilization of carbon compounds by S. eridani (ATCC 21619)

\begin{tabular}{l|c||l|c}
\hline \multicolumn{1}{c|}{ Carbon source } & Growth & Carbon source & Growth \\
\hline Sucrose & ++ & Mannitol & ++ \\
Xylose & ++ & Fructose & ++ \\
Arabinose & ++ & Rhamnose & ++ \\
Inositol & ++ & Cellulose & - \\
Raffinose & ++ & Glucose (positive control) & ++ \\
\hline++ Strongly positive utilization & $-:$ No utilization
\end{tabular}

Table 3. Comparison of $S$. evidani with related strains

\begin{tabular}{|c|c|c|c|c|c|c|}
\hline & $\begin{array}{l}\text { S. eridani } \\
\text { n. sp. }\end{array}$ & $\begin{array}{c}\text { S. albidus } \\
\text { CBS } 100.34\end{array}$ & S. armillatus & $\begin{array}{l}\text { S. diastaticus } \\
\text { ATCC } 3315\end{array}$ & $\begin{array}{l}\text { S. odorifer } \\
\text { ATCC } 6246\end{array}$ & $\begin{array}{c}\text { S. felleus } \\
\text { CBS } 49168 \\
\end{array}$ \\
\hline $\begin{array}{l}\text { Vegetative } \\
\text { mycelium }\end{array}$ & $\begin{array}{l}\text { Amber to } \\
\text { brown }\end{array}$ & $\begin{array}{l}\text { Colorless to } \\
\text { cream }\end{array}$ & $\begin{array}{l}\text { Colorless, } \\
\text { yellow, gray }\end{array}$ & Yellowish & $\begin{array}{l}\text { Cream to } \\
\text { brown }\end{array}$ & $\begin{array}{l}\text { Yellowish, } \\
\text { brown }\end{array}$ \\
\hline $\begin{array}{l}\text { Aerial } \\
\text { mycelium }\end{array}$ & $\begin{array}{l}\text { Scarce, white, } \\
\text { spirals }\end{array}$ & $\begin{array}{l}\text { Whitish, } \\
\text { spirals }\end{array}$ & $\begin{array}{l}\text { Scarce, white, } \\
\text { spirals }\end{array}$ & $\begin{array}{l}\text { White to gray, } \\
\text { spirals }\end{array}$ & $\begin{array}{l}\text { White and } \\
\text { cream, spirals }\end{array}$ & $\begin{array}{l}\text { White-gray, } \\
\text { straight } \\
\text { sporophores }\end{array}$ \\
\hline $\begin{array}{l}\text { Soluble } \\
\text { pigment }\end{array}$ & $\begin{array}{l}\text { Amber to } \\
\text { brown }\end{array}$ & $\begin{array}{l}\text { Yellowish to } \\
\text { brownish }\end{array}$ & Absent & $\begin{array}{l}\text { Colorless to } \\
\text { brown }\end{array}$ & Light brown & $\begin{array}{l}\text { Yellow ish } \\
\text { brown }\end{array}$ \\
\hline $\begin{array}{l}\text { Nitrate } \\
\text { broth }\end{array}$ & Reduction & Slow reduction & No reduction & $\begin{array}{l}\text { Weak } \\
\text { reduction }\end{array}$ & Reduction & ND \\
\hline $\begin{array}{l}\text { Litmus } \\
\text { milk }\end{array}$ & $\begin{array}{l}\text { No coagulation } \\
\text { No peptoniza- } \\
\text { tion }\end{array}$ & $\begin{array}{l}\text { Weak } \\
\text { coagulation, } \\
\text { peptonization }\end{array}$ & $\begin{array}{l}\text { Coagulation, } \\
\text { peptonization }\end{array}$ & $\begin{array}{l}\text { Coagulation, } \\
\text { weak peptoni- } \\
\text { zation }\end{array}$ & $\begin{array}{l}\text { No coagula- } \\
\text { tion, weak } \\
\text { peptonization }\end{array}$ & $\begin{array}{l}\text { No } \\
\text { coagulation, } \\
\text { peptonization }\end{array}$ \\
\hline Gelatin & Liquefaction & Liquefaction & Liquefaction & Liquefaction & $\begin{array}{l}\text { Weak } \\
\text { liquefaction }\end{array}$ & $\begin{array}{l}\text { No } \\
\text { liquefaction }\end{array}$ \\
\hline $\begin{array}{l}\text { Nutrient } \\
\text { agar }\end{array}$ & $\begin{array}{r}\text { V.*: amber } \\
\text { A.*: absent } \\
\text { P.*: amber } \\
\\
\text { brown }\end{array}$ & ND** & ND & $\begin{array}{l}\text { V.: } \text { cream } \\
\text { A.: white to } \\
\text { gray } \\
\text { P.: } \text { brown }\end{array}$ & $\begin{array}{l}\text { V.: brown } \\
\text { A.: } \text { white } \\
\text { P.: light } \\
\\
\text { brown }\end{array}$ & $\begin{aligned} \text { V.: } & \text { yellowish } \\
& \text { brown } \\
\text { A.: } & \text { absent } \\
\text { P.: } & \text { light } \\
& \text { brownish } \\
& \text { yellow }\end{aligned}$ \\
\hline $\begin{array}{l}\text { Glucose } \\
\text { asparagine } \\
\text { agar }\end{array}$ & $\begin{array}{l}\text { V.: cream } \\
\text { A.: absent } \\
\text { P.: cream }\end{array}$ & ND & $\begin{array}{ll}\text { V.: } & \text { yellow- } \\
& \text { gray } \\
\text { A.: } & \text { white } \\
\text { P.: } & \text { absent }\end{array}$ & $\begin{array}{l}\text { V.: yellowish } \\
\text { A.: absent } \\
\text { P.: absent }\end{array}$ & 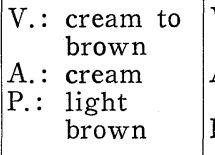 & $\begin{array}{l}\text { V.: } \begin{array}{l}\text { yellowish } \\
\text { brown }\end{array} \\
\text { A.: } \text { white- } \\
\text { gray } \\
\text { P.: brownish }\end{array}$ \\
\hline $\begin{array}{l}\text { Glycerol } \\
\text { asparagine } \\
\text { agar }\end{array}$ & $\begin{array}{l}\text { V.: light } \\
\text { brown } \\
\text { A.: absent } \\
\text { P.: absent }\end{array}$ & ND & $\begin{array}{ll}\text { V.: } & \text { yellow- } \\
& \text { gray } \\
\text { A.: } & \text { white } \\
\text { P.: } & \text { absent }\end{array}$ & ND & ND & $\begin{array}{ll}\text { V.: } & \text { yellowish } \\
\text { A.: } & \text { white- } \\
& \text { gray } \\
\text { P.: } & \begin{array}{l}\text { yellowish } \\
\text { brown }\end{array}\end{array}$ \\
\hline $\begin{array}{l}\text { Czapek } \\
\text { glucose } \\
\text { agar }\end{array}$ & $\begin{array}{l}\text { V.: straw } \\
\text { A.: absent } \\
\text { P.: absent }\end{array}$ & $\begin{array}{l}\text { V.: colorless } \\
\text { A.: white } \\
\text { P.: yellowish }\end{array}$ & $\begin{array}{l}\text { V.: colorless } \\
\text { A.: absent } \\
\text { P.: absent }\end{array}$ & $\begin{array}{ll}\text { V.: } & \text { gray } \\
\text { A.: } & \text { white to } \\
& \text { gray } \\
\text { P.: } & \text { ND }\end{array}$ & $\begin{aligned} \text { V.: } & \text { cream to } \\
& \text { light } \\
& \text { brown } \\
\text { A.: } & \text { cream } \\
\text { P.: } & \text { absent }\end{aligned}$ & ND \\
\hline Starch agar & $\begin{array}{ll}\text { V.: } & \text { straw } \\
\text { A.: } & \text { absent } \\
\text { P.: } & \text { straw } \\
& \text { hydrolysis }\end{array}$ & $\begin{array}{l}\mathrm{ND} \\
\text { hydrolysis }\end{array}$ & $\begin{array}{l}\text { ND } \\
\text { No hydrolysis }\end{array}$ & $\begin{array}{ll}\text { V.: } & \text { colorless } \\
\text { A.: } & \text { gray } \\
\text { P.: } & \text { ND } \\
& \text { hydrolysis }\end{array}$ & $\begin{array}{ll}\text { V.: } & \text { cream to } \\
& \text { brown } \\
\text { A.: } & \text { straw } \\
\text { P.: } & \text { absent } \\
& \text { hydrolysis }\end{array}$ & $\begin{aligned} \text { V.: } & \text { colorless } \\
\text { A.: } & \text { white } \\
\text { P.: } & \text { absent } \\
& \text { hydrolysis }\end{aligned}$ \\
\hline
\end{tabular}

* V. =vegetative mycelium ; A.=aerial mycelium ; P. =soluble pigment.

** No puplished data.

media and for their ability to peptonize milk and to sporulate on media on which $S$. eridani does not. Streptomyces diastaticus ATCG 3315, Streptomyces odorifer ATCG 6246 and Streptomyces felleus CBS 49168, although not belonging to Section Spira, White Series, are similar to our strain in the production of brown pigment and in some other characteristics, but differ in the color of aerial mycelium on several media. 


\section{Production of the Antibiotic}

The culture of S. eridani was maintained on oat-meal agar. Fermentation conditions suitable for the production were studied and the following media were found to be useful:

1) Vegetative medium for shake flask culture (g/liter): beef extract, 5 ; yeast extract, 5 ; peptone, 5 ; enzymatic casein hydrolysate, 3 ; dextrose, 20 ; sodium chloride, 1.5.

2) Vegetative medium for fermentors ( $\mathrm{g} /$ liter): beef extract, 4 ; peptone, $4 ; \mathrm{NaCl}$, 2.5 ; yeast extract, 1 ; soybean meal, 10 ; dextrose, $20 ; \mathrm{CaCO}_{3}, 5$.

3) Fermentative medium: the same as medium 2 with $50 \mathrm{~g} /$ liter dextrose.

For the production of the antibiotic jar fermentors containing 10 liters of medium 3 were inoculated with one liter of vegetative culture and incubated aerobically (1 liter air/liter/min.) under stirring (800 r.p.m.) at $28^{\circ} \mathrm{C}$.

Maximum antibiotic activity was obtained after 48 hours of fermentation. A paper disc agar plate assay with Escherichia coli as the test organism was used to determine the antibiotic levels.

\section{Isolation of Pyracrimycins $A$ and $B$}

The isolation and purification of the two metabolites was followed spectroscopically as both pyracrimycins $\mathrm{A}$ and $\mathrm{B}$ show intense ultraviolet absorptions.

The fermented broth was filtered with the aid of $2 \%$ Hyflo-Super Cel and the mycelial cake discarded. The filtrate, after the addition of $20 \%$ of $\mathrm{NaCl}$ was extracted twice with one-half volume of butanol, the combined extracts were washed with a small volume of slightly alkaline water and concentrated to one fifth of the original volume. A precipitation of inorganic salts, containing less than $1 \%$ of pyracrimycins, was obtained by cooling the concentrated solution for a few hours at $4^{\circ} \mathrm{C}$; the salts were filtered off and the solution concentrated again to a small volume. A crude mixture of pyracrimycins $\mathrm{A}$ and $\mathrm{B}$ was obtained by adding a large excess of petroleum ether to the concentrated extracts. The crude material has about $30 \sim 35 \%$ purity, pyracrimycins $\mathrm{A}$ and $\mathrm{B}$ being present in roughly one to one proportion. The product was suspended in hot methanol $(2 \mathrm{~g} / 100 \mathrm{ml})$ and filtered from insoluble particles; the solution was treated with charcoal to remove impurities and concentrated until crystallization occurred; both metabolites co-crystallize on cooling giving a product with about $95 \%$ total purity. A separation of the two was achieved by treatment of the product on water bath for one hour with chloroform $(1 \mathrm{~g} /$ liter $)$ in which only pyracrimycin $B$ is soluble. Pyracrimycin A, containing only $1 \sim 2 \%$ of $B$, was filtered and pyracrimycin B crystallized after concentration of the chloroform solution to a small volume. A final crystallization from methanol for pyracrimycin $\mathrm{A}$ and from chloroform for $\mathrm{B}$ gave pure products.

\section{Chemico-physical Characteristics}

Pyracrimycin $\mathrm{A}$ is a white crystalline substance, m.p. $215 \sim 216^{\circ} \mathrm{C}$; the product appeared to be unitary by paper and thin-layer chromatographic analyses; the Rf 
Table 4. Chromatographic behavior of pyracrimycin A

\begin{tabular}{|c|c|}
\hline Solvent system & $\mathrm{Rf}^{*}$ \\
\hline Water-saturated $n$-butanol & 0.60 \\
\hline $\begin{array}{l}\text { Water-saturated } n \text {-butanol } \\
\quad+2 \% p \text {-toluensulfonic acid }\end{array}$ & 0.29 \\
\hline $\begin{array}{l}\text { Water-saturated } n \text {-butanol } \\
\quad+2 \% \text { concentrated ammonia }\end{array}$ & 0.53 \\
\hline$n$-Butanol-saturated water & 0.14 \\
\hline $\begin{array}{l}\text { Ammonium chloride ( } 20 \% \text { solution in } \\
\text { water) }\end{array}$ & 0.71 \\
\hline $\begin{array}{l}\text { n-Butanol - methanol - water ( } 40: 10: \\
\text { 20) containing } 0.75 \mathrm{~g} \text { methyl orange }\end{array}$ & 0.65 \\
\hline n-Butanol - methanol - water $(40: 10: 30)$ & 0.71 \\
\hline Water-acetone $(1: 1)$ & 0.52 \\
\hline Water-saturated ethyl acetate & 0.0 \\
\hline Chloroform-methanol $(9: 1)$ (TLC)** & 0.22 \\
\hline
\end{tabular}

* Paper chromatography on Whatman No. 1, antibiotic visualized on agar plates seeded with $S$. aureus.

** TLC performed on Silica-gel $\mathrm{HF} / \mathrm{UV}_{254}$ plates to a distance of $10.0 \mathrm{~cm}$; spot detected under UV light.

values obtained with different solvent systems are reported in Table 4 . The following microanalytical data C 60.99, $\mathrm{H} 7.50, \mathrm{~N} 20.20 \%$ are consistent for a molecular formula $\mathrm{C}_{7} \mathrm{H}_{10} \mathrm{~N}_{2} \mathrm{O}$ (theoretical values: $\mathrm{C} 60.85, \mathrm{H} 7.30, \mathrm{~N} 20.27$ with a molecular weight 138.17). The product has slightly basic character. It is almost insoluble in the common organic solvents, with the exception of dimethylsulfoxide and dimethylformamide and slightly soluble in acidic water and methanol. The ultraviolet spectrum in methanol solution shows a maximum at $235 \mathrm{~m} \mu(\varepsilon 24,000)$.

Pyracrimycin B is a light yellow crystalline substance, m.p. 222 $224^{\circ} \mathrm{C}$. Thinlayer chromatographic analysis gave $\mathrm{Rf} 0.30$ in the same conditions as for pyracrimycin A. The following microanalytical data C 54.38, H 6.59, N 18.29, are consistent for a molecular formula $\mathrm{C}_{7} \mathrm{H}_{10} \mathrm{~N}_{2} \mathrm{O}_{2}$ (theoretical values $\mathrm{C} 54.54, \mathrm{H} 6.54, \mathrm{~N} 18.17$ with a molecular weight 154.7). The product is soluble in dimethylsulfoxide, dimethylformamide and methanol, slightly soluble in chloroform and alkaline water. The ultraviolet spectrum in methanol solution shows a maximum at $332 \mathrm{~m} \mu(\varepsilon 16,000)$.

The structure of trans 3-(1-pyrrolin-2-yl)acrylamide for pyracrimycin A was determined as described in the following paper. ${ }^{7)}$

\section{Biological Properties of Pyracrimycin A}

The antibiotic is active in vitro against a variety of Gram-positive and Gramnegative bacteria and it presents no cross-resistance with a series of $E$. coli strains resistant to different antibiotics. The antibacterial spectrum of pyracrimycin A determined according to the serial dilution method in Difco Pennassay broth is reported in Table 5 . The acute toxicity in mice is about $150 \mathrm{mg} / \mathrm{kg}$ by intraperitoneal route. 
Acknowledgements

The authors wish to thank Dr. R. Pallanza for in vitro activity data and Mr. A. Binaghi for chromatographic analysis.

\section{References}

1) Shirling, E. B. \& D. Gottlieb: Methods for characterization of Streptomyces species. Intern. J. Syst. Bact. $16: 313 \sim 340,1966$

2) Waksman, S. A.: The Actinomycetes. vol. II. The Williams and Wilkins Co., 1961

3) Hickey, R. J. \& H. D. Tresner: A cobalt containing medium for sporulation of streptomyces species. J. Bact. $64: 891 \sim 892,1952$

4) Maerz, A. \& M. R. PAUl: A Dictionary of Color. McGraw-Hill Inc., N. Y., 1950

5) Pridham, T. G.; C. W. Hesseltine \& R. G. Benedict: A guide for the classification of streptomycetes according to selected groups. Appl. Microbiol. $6: 52 \sim 69,1958$

6) Pridham, T. C. \& D. Gotrlieb: The utilization of carbon compounds by some Actinomycetales as an aid for species determination. J. Bact. $56: 107 \sim 114,1948$

7) Coronelli, C.; A. Vigevani, B. Cavalleri \& G. G. Gallo: Structure determination of pyracrimycin $A$, a new antibiotic substance. J. Antibiotics $24: 497 \sim 502,1971$ 